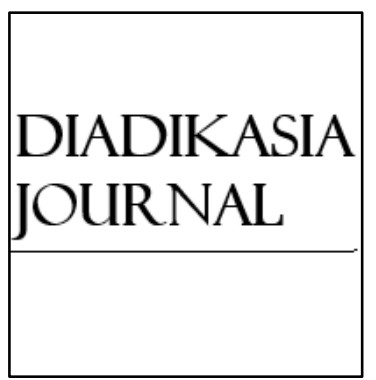

Diadikasia Journal

ISSN: $2721-9070$

Copyright $\odot 2020$ Diadikasia Organization

https://diadikasia.pubpub.org/

Volume 1(1): 93-102

DOI: $10.21428 / 8 c 841009 \cdot 9 f 295293$

\title{
HOAX: TECHNOLOGICAL MECHANISMS, MORAL DEGRADATION, AND CRITICAL LOSS OF SOCIETY'S REASON
}

\author{
Habibi Habibi \\ abiebdragx@student.uns.ac.id \\ Universitas Sebelas Maret \\ Jl. Ir. Sutami No. 36A, Surakarta, Indonesia 57126
}

\begin{abstract}
Since 2014 after the General Elections in Indonesia, the public information space has been decorated with a lot of hoax information, which is false information with malicious content that can cause readers to misread something. This phenomenon is increasingly rife every time it approaches political performances. There is a big suspicion that certain actors deliberately create hoax information for specific purposes. On that basis, in this study, three main issues are raised namely, why do people have the heart to deceive others by spreading hoax information on social media, and how can people with good heads be fooled by it, finally, how the impact of hoaxes on social life. This study uses a qualitative method with a literature study approach. The results found that the hoax deliberately built for political purposes by utilizing technological objectives and attacking vulnerable groups categorized as "digital native." The impact of a hoax is hazardous for the community because it can trigger a prolonged horizontal conflict.
\end{abstract}

Keywords: Hoax, Filter bubble, Digital literacy, Culture studies, Discourse.

\section{Introduction}

In recent years, the world rocked by the outbreak of the hoax phenomenon that has damaged the circulation of public information. This commotion began around the year 2012. George (2015) noted the emergence of hoaxes in various countries, especially countries that embrace a democratic system based on his government, including Indonesia. The tendency of this pattern invites suspicion that hoaxes are not a social reality of people who are born naturally; on the contrary, this becomes a kind of sign that hoaxes deliberately raised and born. Hoax, according to Astuti (2017), is false or false news or information deliberately made to disguise the truth and function to manipulate the reader's attention. 
According to Ali (2014), information on hoaxes began to emerge in Indonesia since mid-2014 and has gradually increased. At the same time, Indonesia was holding a national-scale political contestation, namely the election. Hoax interconnected on social media by taking much public attention, the article many hoaxes that spread carrying information twisted in such a way about political actors who will fight in the contestation. The political actors with the most information on hoaxes are presidential and vice-presidential candidates in 2014, namely Prabowo Subianto and Hatta Rajasa, presidential candidates, and vice-presidential candidates sequence number 1 and Joko Widodo paired with Jussuf Kalla as presidential candidates and candidates vice president with serial number 2 .

Why is the information hoax developing and becoming more and more in terms of numbers when approaching the political year. This fundamental question leads to the assumption that hoaxes are a political maneuver to get public attention. According to Utami (2018), hoax themes that often appear on the internet always contain political elements. Hoaxes carry narratives that can build and weaken a person's electability. Therefore, there is a high possibility that certain groups intentionally built hoaxes for political purposes.

Many people deceived by hoax news, and not a few of them end up participating in spreading hoax information on social media; this is an indicator that the person has been exposed and is a victim of false information. The impact, hoaxes will spread and touch many people, which means opening up the potential for new victims. On the other hand, the impact will be hazardous because it can trigger people to consider false information as truth. Even Haryati (2017) states that hoaxes can work as a means of public fraud and trigger public panic in the real world.

Septanto (2018) explained that unconsciously, people would assume something that he doubted turned into truth if the information continued to be present in his life. Algorithms that are owned by social media today, such as Facebook, Instagram, and Twitter, actually support that condition. Pariser (2012) found that social media implemented an algorithm that he called "filter bubble," a mechanism that must display content relevant to social media users. The information that roams there comes from the results of the user's activity filter. Indirectly, this algorithm will ensnare the user to the information he likes only and closes the opportunity for other information to enter in a person's social media circle.

On that basis, many results of the analysis and research conclude that social media contributes to a broad avenue for hoax information flow to pass through and greet many people at once. Rifauddin (2018), for example, explained that social media succeeded in replacing the role of conventional media and was able to shift it, becoming an essential reference for people searching for information. This shift provides space for hoax information to proliferate in recent years, while, according to Parahita (2018), social media equipped with advanced technology and applying interactive communication models have extensive capabilities in disseminating information, including information 
hoaxes. This capability, cutting age limits, areas, and cognitive tendencies that allow the visibility of hoax information is increasing. Nevertheless, Sabani (2018) explained that hoaxes arose not merely on the ease of obtaining, creating, and disseminating information through social media but also based on the psychological vulnerability of its users in making and receiving information on social media.

Many interpretations make social media or the rise of the era of communication and information technology as the leading cause of hoaxes (Syuhada, 2017), whereas when looking at history, hoaxes have existed since before the technology invented but in different forms. According to Sokal (2010), hoaxes grow in line with the ability of human language and culture, born in every era of human history civilization; it's just different in symbols and symptoms. This opinion becomes a fundamental foundation in seeing the history of hoaxes when related to historical events that have occurred. For example, the events of the massacre of Jewish ethnicities by the Nazis in Europe (Steers Jr., 2013), the G30SPKI in Indonesia, to the issue of Iraqi engineering weapons were blown by America to kill Sadam Hussein and devastate Iraq until this moment. That fact happened thanks to hoaxes' ability to grab the attention of the public, and social media did not exist at that time.

That is, hoax can be systematically and effectively used to deceive the community, and it does not depend on any medium. In this case, social media is just a tool for sharing information; on the other hand, hoaxes have a hazardous effect because they can manipulate public awareness and use them to gain power, at a more chronic level, hoaxes are very dangerous because they can take someone's life. Based on the above explanation, at least three main problems encountered. First, why do so many people with logical minds get fooled by hoaxes? Why does this happen? These problems narrowed to the assumption that hoaxes intended to deceive, and why do people have the heart to do it? Furthermore, finally, how is the danger of hoaxes for the community?

\section{Methods}

This research included in the type of qualitative research by taking the primary data sources from books, newspapers, articles, and related literature on hoaxes. Zed (2004) explains that the primary ability of a literature study is to capture the root of the problem more comprehensively because of the analysis based on sources that can be referenced and accounted for. Meanwhile, according to Gunawan (2013), research-based on qualitative methods allows researchers to provide in-depth interpretations of a problem and produce information in the form of notes and comprehensive descriptive data. Methodologically, this study places hoaxes as text and at the same time as Discourse.

According to Foucault, individuals/subjects are formed by Discourse, so that the institutionalized hoax in a text contains Discourse built by the author for a specific purpose (Hall, 2001). Through these texts, this research traces the web of Discourse and looks for what happens behind the hoax phenomenon? The technical step taken is to 
sort out the texts that were examined and randomly selected, considering that the text contains misleading hoax information. Data analysis based on the initial steps taken by collecting the required data, then classification and description are carried out.

\section{Discussion}

Within four years, the phenomenon of hoaxes in Indonesia is widespread and rapidly developing. From 2014 to 2018, hoax continues to decorate public information channels. George (2015), in his article, explained earlier that hoaxes began to grow in democratic system countries since 2012. In Indonesia, the spread of hoaxes began to increase sharply when the 2014 elections held.

If so, the core problem of hoaxes is political, that is, an attempt by a group of actors who twist information into hoaxes to smooth out a particular goal. In this proposition, what makes sense to question is why people with logical minds can be fooled by it? Moreover, how can the deceptive activity be an everyday thing? So, what culture does hoax reflect? These questions become the foundation in dismantling the hoax phenomenon that has been circulating widely and endangers the community because it can mislead public information channels.

\section{A. Hoaxes, Social Media, and Bubble Filters}

In 2011, Pariser, an internet activist, discovered an algorithm that planted on social media, which he named "Filter Bubble." Algorithms work to collect social media user information such as clicks, likes, and all other activities. This data collection is used by social media managers to support customers' needs in marketing their products on social media. With this database, advertisements can be displayed as the relevant content for social media users so that the percentage of product sales can rise.

However, there is a dark side to the filter bubble discovered by Pariser, that this feature is dangerous because it records all user activities and sells them to third parties for the benefit of social media owners. Besides, this feature can also accurately calculate a person's information, which can eventually be used as a calculation to set user preferences. The other dark side is that this feature closes one's intellectual and critical space because as long as it is activated, it will only display information that is suitable for its preference so that one's tendency to become fanatic on one information is greater (Bozdag, 2015). This condition allows the control of public opinion by relying on social media and seems to be very beneficial if used for political purposes such as gaining support, eroding the electability of political actors, and so on.

The ability of bubble filters to record privacy data on social media users opens opportunities for certain actors to use the data as a tool to achieve their strategic objectives, not least in politics. Howell's opinion (2019) can inform the above argument that hoaxes were deliberately raised for political tools-referring to the site of Turnbackhoax.id hoax, information data that emerged between 2014-2018 in Indonesia 
dominated by political information. The content in it brings issues related to ethnicity, race, religion, and between groups, attributed to someone competing in the political stage (Pilkada, Election). As a percentage, hoax information exploded in numbers as the political year approached and gradually declined after the political performance was over.

Social media is a very vulnerable container and is often used to spread hoax news (Rogers, 2018). The number of active users can even be said to be a social media enthusiast in Indonesia; this greatly facilitates the spread of hoax in acting. From the results of a survey on national hoax outbreaks conducted by Mastel (2017) that the channel or channel for disseminating news or information that contains the highest hoax content is from social media in the form of Facebook at the highest order of $92.40 \%$, chat applications $62.80 \%$, and website $34.90 \%$. Research conducted by Ruri Rosmalinda (2017) about "the phenomenon of Misdirection of News on Social Media" states that the influence of technological developments can be a global threat, including Indonesia, specifically related to the spread of hoaxes.

According to KOMINFO data (2019), a total of 1,731 hoax news published on the internet from August 2018 to April 2019 were identified, verified, and validated by the AIS Team in the Ministry of Communication and Information Technology, the political category hoaxes dominated in 620 items of hoaxes and followed by 210 hoaxes in the government category, 200 hoaxes in the health category, 159 hoaxes related to defamation, 113 hoaxes related to crime and the rest hoaxes related to religious issues, natural disasters, myths, international and other issues. The increase in hoax information occurred in April-August 2019 and dominated by the political category hoax. The findings of this data strengthen the assumption that hoaxes are born intentionally and spread for specific purposes. According to Posetti \& Matthews (2018), after the incident of selling Facebook user data to Cambridge Analytica was revealed, hoaxes began to become one of the most effective ways for political actors to demonstrate themselves in order to gain the attention and support of the masses.

One of the hoaxes circulating in April 2019 and successfully verified by the Forum Anti Fitnah, Hasut and Hoax (FAFHH) was regarding the depravity of the KPU (General Elections Commission of Indonesia) because they were willing to take bribes to win one of the parties in the April 2019 Election.

Figure 1: Screenshot of a confirmed hoax article on the Turnbackhoax.id site

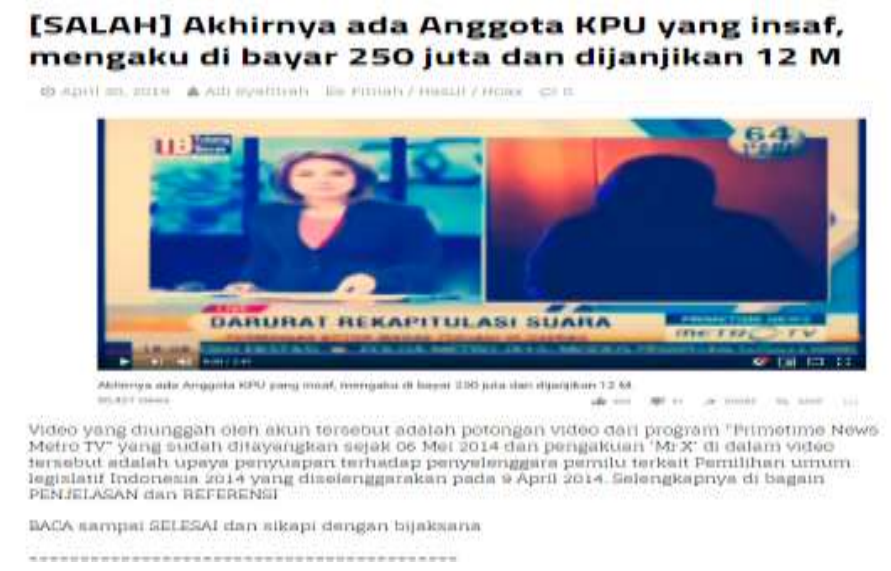

97 | Diadikasia Journal. Vol. 1 No. 1, April 2020 
The hoax article above published on April 24, 2019, spread on social media Youtube with a video format that explains that there is one member of the General Elections Commission of Indonesia (KPU) who claimed to have paid 250 million to win one of the candidates for politicians competing in the legislative elections on April 9, 2014. This news published in the 2019 Election with content related to the 2014 election theme in Indonesia. The image that is trying to build is to inform the public that political performances are never free from acts of corruption and bribery, ultimately eliminating public trust in the political system in Indonesia in this case the General Elections Commission of Indonesia (KPU) as the official institution governing the elections and elections.

The context that is happening when in April 2019 is that Indonesian society divided into three camps, namely the first camp supporting supporters of the presidential and vice-presidential candidates Prabowo-Sandiaga. Second, supporters of the presidential and vice-presidential strongholds of Jokowi-Ma'ruf are the last ones to choose abstentions. The above article was published when the recapitulation of the results of the election was taking place. Connotatively this article tries to plunge the image of the KPU (General Elections Commission of Indonesia) so that the public rejects the results of vote recapitulation because it considered in the counting process to halted using bribery, nepotism, and the like. The purpose of launching this information is to repeat the election to save the faction that has lost the votes count to win the election.

The hoax information above succeeded in influencing the public to place hatred towards the General Elections Commission (KPU) and urged the government to reelection. Demonstrations took place in various places, many political analyst experts who argued that the current conditions could have led to Indonesia in a more significant conflict than in May 1998.

What needs to observe in this event is the role of social media in taking public attention. With some hoax information, hundreds or even millions of people fooled (Shifman, 2014). Miller (2020) Explains how a digital culture born due to the use of social media in society can significantly affect society's condition. The upheaval that occurs in social media will have a significant impact on the development of society in the real world. That is, social media has robust controls in human life today. When political actors understand that fact and understand a little about the bubble filter algorithm, they can easily lead public opinion to smooth their objectives. On that basis, Wiggins (2019) states straightforwardly that the real hoax does not change rumors, gossip, and the like that exist in the daily lives of humans in the real world, the difference between hoaxes given more comprehensive visibility thanks to technological developments and that is further compounded by digital capabilities very less literacy from social media users.

A more extreme point of view is explained by Bakir \& McStay (2018) that hoaxes are a hate industry that generates money, in which there is economic turnover, which is orchestrated by several parties for financial gain. This opinion based on the scandal of selling Facebook user data to Cambridge Analytica that the user data can calculate by 
using filter bubbles to determine the percentage of someone's electability, advertisements, and the like. Some parties play the user's private data and make it a benchmark of strategy.

According to Pangrazio (2018), what is needed now is digital literacy knowledge. This ability functions so that humans can adapt to technological developments very quickly. The fact that there are still many people who are victims of hoaxes is an indicator that there are still many people who do not understand digital literacy, and that is a lag. The Qibla of Information has now shifted from conventional media that applies journalistic ethics to interactive social media, so the perspective in seeing information must also be considered comparative because everyone can publish news and share it. Through digital literacy observations, hoaxes will be very easily recognized.

Social media indeed makes hoax spread faster and can provide a broad road to target millions of people at once, but social media is not a free place. Mechanically, social media allows all users to create news and information along with features to share it. However, Pariser's (2012) findings of the filter bubble enlighten the answer that all information on the internet, especially social media, has been designed in such a way as to have a specific purpose, meaning that the information contained certain people produce there for their purposes. For that reason, blaming social media as the source of hoaxes is a fatal mistake. Supriatna's article (2018) published in Indoprogress magazine can justify that social media is only a medium of communication and socialization tools, not unlike newspapers and such only in social media embedded interactive features that allow fellow users to communicate with each other.

\section{B. The Hoax Phenomenon as a Reflection of Moral Degradation and the Critical Loss of Society's Reason}

Hoax information that is increasingly spreading in the public communication space seems to be masterminded by a handful of people to accomplish their interests by utilizing technological advances. However, why do people have the heart to cheat in order to realize a desire and why many people are deceived by it. The hoax phenomenon in Indonesia for Salam (2018) considered as a political effort that puts forward antidiversity themes to bring back the nation's collective memory. This effort considered political because its impact can divide the sense of national unity just to divide the support of the masses and scoop it up as electoral capital when the political period lasts. On that basis, hoaxes are symptoms that reflect a culture in Indonesian society, exceptionally modern society today.

Utilizing hoaxes as a tool to realize goals is an indicator of the decline of human civilization. Deceiving, lying, and twisting information in public spaces is common. That is, hoaxes are not just a matter of information but are closely related to the nation's moral problems. Unfortunately, the perpetrators of hoax spreaders have quite extensive influence and vocal vibrations in the community (Takolander \& McCooey, 2004). 
On the other hand, Astuti (2017) explained that digital media currently dominated by teenagers born in the millennium, which are "digital natives," namely generations that cannot be separated by the digital world. This group determined by the age range of birth years between 1982-2000s. This native digital generation is vulnerable to information about hoaxes spread through social media. The reason is that the "digital native" group does not recognize conventional information sources such as newspapers, radio, and magazine rubrics that promote journalistic ethics. As a result, as the successor group of the nation, they experience a decline in critical reason and are vulnerable to manipulation.

Meanwhile, according to Syahputra (2017), the current outbreak of hoax information is based on a democratic climate that gives euphoria of freedom of speech by relying on that proposition ultimately without hesitation, participate in making and sharing wrong information. However, is it true that the group "digital native" loses critical reason and enjoys the freedom of opinion without considering the consequences? What if this deliberately made?

The assumption that the "digital native" group naturally herded to quickly receive hoax information while spreading it starts with Pariser's findings of "filter bubbles." Right, the "digital native" group is vulnerable to hoax information. However, the fact that hoaxes deliberately produced is an essential reference that social media users intentionally directed to enjoy hoax information by their producers this is logical because according to data from the APJII survey in Astuti (2017) the majority of social media users are community groups in the age range of 20-24 years. The main base of producers to spread hoaxes is on social media, meaning that they deliberately attack groups that most easily exposed to information about hoaxes that are "digital native" groups so that it is likely that hoaxes have been constructed for the consumption of these circles to be consumed by the makers.

Another indicator explained by Susanto (2017) is that the assumptions about hoaxes spread in a way that targets the "digital native" group based on the experience of the Indonesian people. In the New Order era, the dissemination of information was closely monitored by the government in power as the party with high power in controlling the mass media for the government's political interests. Institutions or institutions are managing conventional mass media considered as media that are not free from political influence or interested capital owners looking for profit. That is, it does not rule out that the media today is still controlled by power. This calculation brings observations to the correlation between communication and information culture in Indonesia, which is morally degraded and explains that hoaxes made in such a way as to harm humanity by providing broad avenues for false information to circulate and forcing the next generation to devour it to the end. In the end, the hoaxes phenomenon reflects the decline in national morale and a sign of the loss of critical reasoning of the nation's successors. Therefore, the study results of Legionosuko \& Harowo (2017) explain that hoaxes can trigger horizontal conflicts in the community; this can happen, considering the primary purpose of the hoax spread is this condition. 


\section{Conclusion}

The phenomenon of hoaxes that are becoming more prevalent occurs as a social phenomenon closely related not only as a matter of mere information and communication. However, it is closely related to the nation's moral issues and people's critical reasoning in understanding information in public space. Technological advances and Pariser's findings of "filter bubbles" are the necessary references that there are groups of people who use hoaxes as a way to smooth their interests by leading public opinion. The content of hoax information, which is dominated by political content, brings the observation that hoaxes deliberately created for political purposes. Based on freedom of speech in a democratic system, deceiving others with false information is natural, this condition shows the moral degradation of society today, and that relief works because not a few people exposed to hoax information. The number of hoax victims is increasing day by day, reflecting the loss of critical reasoning in today's society in response to information. As a result, hoax information effectively becomes a way to manipulate public attention and can even easily create horizontal conflict in the community.

\section{References}

Ali, M. (2017), Melawan Hoax di Media social dan Media Massa. Yogyakarta: Askopis Press.

Astrini, A. (2017). Hoax Dan Banalitas Kejahatan. Jurnal Transformasi, (32).

Astuti, Y. D. (2017). Peperangan Generasi Digital Natives Melawan Digital Hoax Melalui Kompetisi Kreatif. Informasi, 47(2), 229-242.

Bakir, V., \& McStay, A. (2018). Fake news and the economy of emotions: Problems, causes, solutions. Digital journalism, 6(2), 154-175.

Barker, C. (2003). Cultural studies: Theory and practice. Sage.

Bozdag, E., \& van den Hoven, J. (2015). Breaking the filter bubble: democracy and design. Ethics and Information Technology, 17(4), 249-265.

George, C. (2015). Hate speech law and policy. The International Encyclopedia of Digital Communication and Society, 1-10.

Gunawan, I. (2013). Metode penelitian kualitatif. Jakarta: Bumi Aksara.

Habibi, H. (2018). Protecting National Identity Based On The Value Of Nation Local Wisdom. International Journal of Malay-Nusantara Studies, 1(2), 24-40.

Hall, S. (2001). Encoding/decoding. Media and cultural studies: Keyworks, 2.

Hall, S. (2001). Foucault: Power, knowledge and

Haryati, S., \& Hidayati, D. N. (2017). Hoax News: Promoting the Students' Critical Thinking in Critical Reading Class. Register Journal, 10(2), 122-139.

Haryatmoko. (2007). Etika komunikasi: manipulasi media, kekerasan, dan pornografi. Kanisius.

Howell, A. R. (2019). Politics, Memes, and Culture Jamming: Meme Culture's Potential to Engage Youth in Politics.

Legionosuko, T., \& Harnowo, S. (2018). Dinamika Fake News Atau Hoax Sebagai Sumber Konflik Horisontal Pada Pilkada Propinsi DKI Tahun 2017. Damai dan Resolusi Konflik, 3(3).

Mihailidis, P., \& Viotty, S. (2017). Spreadable spectacle in digital culture: Civic expression, fake news, and the role of media literacies in "post-fact" society. American behavioral scientist, 61(4), 441454.

Miller, V. (2020). Understanding digital culture. SAGE Publications Limited. 
Pangrazio, L. (2018). What's new about 'fake news'?: Critical digital literacies in an era of fake news, post-truth and clickbait. Páginas de educación, 11(1), 6-22.

Pariser, E. (2011). The filter bubble: What the Internet is hiding from you. Penguin UK.

Pembayun, J. G., \& Mahendradi, R. M. (2019). Sikap Digital Natives Terhadap Informasi Hoax di Facebook Menjelang Pilpres 2019. Jurnal Komunikasi dan Kajian Media, 3(2), 144-158.

Posetti, J., \& Matthews, A. (2018). A short guide to the history of 'fake news' and disinformation. International Center For Journalists, 2018-07.

Rifauddin, M., Halida, A. N. (2018). Waspada cybercrime dan informasi hoax pada media sosial facebook. Khizanah al-Hikmah : Jurnal Ilmu Perpustakaan, Informasi, dan Kearsipan. 6(2), 98111.

Rogers, R. (2018). Social media research after the fake news debacle. Partecipazione e Conflitto, 11(2), 557-570.

Sabani, N. (2018). Generasi Millenial Dan Absurditas Debat Kusir Virtual. Informasi, 48(1), 95-108. Utami, P. (2018). Hoax in modern politics: the meaning of hoax in indonesian politics and democracy. Jurnal Ilmu Sosial dan Ilmu Politik, 22(2), 85-97.

Salam, A. (2018). The Hoax Phenomenon in Indonesian Society: Observing Anti-Diversity Memes since 2014. Humaniora, 30(3), 315.

Septanto, H. (2018). Pengaruh hoax dan ujaran kebencian sebuah cyber crime dengan teknologi sederhana di kehidupan sosial masyarakat. dalam Jurnal Kalbiscientia: Jurnal Sains dan Teknologi, 5(2).

Shifman, L. (2014). Memes in digital culture. MIT press.

Sokal, A. (2010). Beyond the hoax: Science, philosophy and culture. OUP Oxford.

Steers Jr, E. (2013). Hoax: Hitler's Diaries, Lincoln's Assassins, and Other Famous Frauds. University Press of Kentucky.

Susanto, E. H. (2017). Media sosial sebagai pendukung jaringan komunikasi politik. Jurnal Aspikom, 3(3), 379-398.

Syahputra, I. (2017). Demokrasi virtual dan perang siber di media sosial: Perspektif Netizen Indonesia. Jurnal Aspikom, 3(3), 457-475.

Syuhada, K. D. (2018). Etika media di era "post-truth". Jurnal Komunikasi Indonesia, 75-79.

Takolander, M., \& McCooey, D. (2004). Fakes, literary identity and public culture. Journal of the Association for the Study of Australian Literature: JASAL, 3, 57-65.

Wiggins, B. E. (2019). The discursive power of memes in digital culture: Ideology, semiotics, and intertextuality. Routledge.

Zed, M. (2004). Metode peneletian kepustakaan. Yayasan Obor Indonesia.

Cite: Habibi, H. (2020). Hoax: Technological Mechanisms, Moral Degradation, and Critical Loss of Society's Reason. Diadikasia Journal, 1(1), 93-102. https://doi.org/10.21428/8c841009.9f295293 